\title{
Farmer's perception on ticks problems and ethnoveterinary management practices in livestock
}

\author{
Bigya Dhital \\ Nepal Polytechnic Institute, Purbanchal University, Nepal. Email: nepalvetbigya@gmail.com \\ Copyright ( 2018 Dhital. This article remains permanently open access under the terms of the Creative Commons Attribution License 4.0, which \\ permits unrestricted use, distribution, and reproduction in any medium, provided the original work is properly cited.
}

Received 17th September, 2018; Accepted 18th October, 2018

\begin{abstract}
Ticks cause serious problems in livestock production. A survey was conducted to know the farmers perception on ticks problems and management practices in livestock at Lamjung, Chitwan and Dang districts, Nepal in 2017/018. Thirty households from each district were randomly selected and semi-structured questionnaire was used to collect necessary information by face-to-face interview. Pest problem has shown an increase in all three surveyed areas. Similarly, less than half respondent in Dang (43.33\%) followed by Lamjung and Chitwan (36.66\%) responded weight losses as the main problem due to ticks in livestock. Neem was found most used plant material to control ticks in all areas as nearly half in Lamjung (46.66\%), Chitwan (46.66\%) and Dang (40.00\%). Additionally, highest numbers of farmer were found using salt water to control ticks. This study clearly shows that ethno-veterinary management practices are also followed by farmers to manage ticks problem in livestock, whose further study is necessary.
\end{abstract}

Key words: Ethnoveterinary, farmer perception, livestock, survey, ticks.

\section{INTRODUCTION}

The livestock sector is an important component of the Nepalese economy. Agriculture accounts for $35 \%$ of the gross domestic product (GDP) and the livestock subsector of agriculture contributes $25.68 \%$ of the agricultural GDP (ADS, 2012; MoAD, 2014). It is an integral part of Nepalese farming, providing draught power, fertilizer and household fuel. In the hills and mountains, mules, yaks, sheep and goats make an important contribution as pack animals (Upadhyay et al., 2017).

It has been studied that about $80 \%$ of the world cattle population is infested with ticks (Bowman et al., 1996). Moreover, ticks cause transmission of viral, bacterial and protozoan pathogens causing diseases like haemorrhagic fever, ehrlichiosis, anaplasmosis, theileriosis, and babesiosis in meat and dairy animals (Rajput et al., 2006). Similarly, they cause loss in productivity and economic gains in livestock industry by blood loss, hide damage, injection of toxins and diseases transmission (Ducornez et al., 2005; Alemu et al., 2014). Ticks have capacity to develop resistance to acaricides as a result it always difficult to control (Itty et al., 1995; Castro-Janer et al., 2010; Mendes et al., 2011; Kumar et al., 2011). Ticks create predominant problems throughout the year in hilly areas (Sarani et al., 2014). They caused very serious problems to resource-poor farming communities worldwide (Mondal et al., 2103; Wanzala et al., 2012; Domingues et al., 2012). Although ticks and ticks associated problems are reported as a serious problem in livestock, very few studies were conducted in Nepal. Some published works on ticks related study in Nepal are Shrestha et al. (2005); Bohara and Shrestha, (2016); Gupta et al. (2013). Unfortunately, there were no any study on farmer knowledge and practices on tick problems and its management practices in Nepal. Hence, it seems necessary to collect and analyze farmer's perception regarding ticks problem on their livestock and their management practices to overcome or control this problem.

\section{METHODOLOGY}

A survey was conducted in three different districts namely Lamjung (Sundarbazzar municipality); Chitwan (Kalika 
Table 1. Times of livestock keeping by farmers in Lamjung, Chitwan and Dang, 2017/018.

\begin{tabular}{lccc}
\hline Times of keeping livestock & Lamjung & Chitwan & Dang \\
\hline $1-3$ years & $3.33 \%$ & $6.66 \%$ & $0.00 \%$ \\
$4-7$ years & $16.66 \%$ & $20.00 \%$ & $13.33 \%$ \\
7-10 years & $23.33 \%$ & $26.66 \%$ & $23.33 \%$ \\
More than 10 years & $56.68 \%$ & $46.66 \%$ & $63.66 \%$ \\
\hline
\end{tabular}

Table 2. Purpose of livestock keeping by farmers in Lamjung, Chitwan and Dang, 2017/018.

\begin{tabular}{lcccc}
\hline Purpose of livestock keeping & Lamjung & Chitwan & Dang \\
\hline Household consumption & $13.33 \%$ & $3.33 \%$ & $6.66 \%$ \\
Commercial & $10.00 \%$ & $23.33 \%$ & $20.00 \%$ \\
Both household consumption and commercial & $76.66 \%$ & $73.33 \%$ & $73.33 \%$ \\
\hline
\end{tabular}

Municipality and Bharatpur Metropolitan City); and Dang (Lamahi municipality) in 2017/018. The survey areas consist of mid hills to terai region of Nepal. Sundarbazzar, Lamjung lies in mid hills; Bharatpur and Kalika Municipality, Chitwan lies in inner terai region; whereas, Lamahi, Dang lies in terai region of Nepal. The climatic condition included from tropical to subtropical type.

Household $(\mathrm{HH})$ survey was the basic sampling unit for collecting the necessary information. The semi-structured questionnaire was prepared, pre-tested and improved to know the livestock farming and problem, external parasite problem, ticks problem, economic damages due to ticks, their management practices at farmer's level. A formal survey was conducted by interviewing thirty randomly selected livestock keeper in each surveyed areas. The data were collected by face-to-face interview and available data were subjected to analysis.

\section{RESULTS}

\section{Farmers' years of livestock keeping}

Regarding farmers' years of livestock keeping, majority were found keeping livestock more than ten years in all three districts (Table 1). Very few farmers were recorded keeping livestock for less than three years, in Lamjung (3.33\%) and Chitwan (6.66\%) whereas in Dang all the farmers have been keeping livestock for more than three years. Nearly, one-fourth of the farmers were found keeping livestock for seven to ten years, in Lamjung (23.33\%), Chitwan (26.66\%) and Dang (23.33\%) (Table 1).

\section{Purpose of livestock keeping}

Table 2 clearly shows the main purpose of livestock keeping as for both household consumption and commercial if production is surplus in all three surveyed areas. The highest was recorded in Lamjung (76.66\%) followed by equal values in Chitwan and Dang (73.33\%). For commercial purpose, the highest was found in Chitwan $(23.33 \%)$ followed by Dang (20.00\%) and least in Lamjung $(10.00 \%)$.

\section{Pest problem in present as compare to past}

More than half of the respondents believed that pest problems has increased in present time as compared to past. Highest numbers of farmers in Lamjung (66.66\%) believed that there is increase in the pest problem and about one-fifth (26.66\%) believed that the problem remain the same, whereas very few believed pest problem is decreasing as compare to past. Similar trends were found in Chitwan and Dang (Table 3).

\section{External pest problem}

Slightly less than half the respondents ranked flies as the major external pest in all surveyed areas. Lamjung and Dang recorded $46.66 \%$ each followed by Chitwan $(43.33 \%)$. Ticks were reported second major pest after flies and the highest was recorded in Lamjung (33.33\%) followed by equal values in Chitwan and Dang (26.66\%). Similarly, fleas and louse were also reported external pest problems respectively in Lamjung $(10.00 \%, 6.66 \%)$, Chitwan (13.33\%, 10.00\%) and Dang (10.00\%, 13.33\%). Finally, mites ranked as least problem in this category in all three districts viz 3.33\% in Lamjung and Dang, 6.66\% in Chitwan (Table 4).

\section{Farmer perception on major problems caused by ticks}

Majority of the farmers reported weight loss as the main 
Table 3. Experience about difference in pest problem in present as compare to past in Lamjung, Chitwan and Dang.

\begin{tabular}{lccc}
\hline Pest problem in present as compare to past & Lamjung & Chitwan & Dang \\
\hline Increasing & $66.66 \%$ & $56.66 \%$ & $60.00 \%$ \\
Decreasing & $6.66 \%$ & $10.00 \%$ & $3.33 \%$ \\
Constant & $26.66 \%$ & $33.33 \%$ & $36.66 \%$ \\
\hline
\end{tabular}

Table 4. External pest problem in Lamjung, Chitwan and Dang.

\begin{tabular}{lccc}
\hline External pest & Lamjung & Chitwan & Dang \\
\hline Ticks & $33.33 \%$ & $26.66 \%$ & $26.66 \%$ \\
Flies & $46.66 \%$ & $43.33 \%$ & $46.66 \%$ \\
Mites & $3.33 \%$ & $6.66 \%$ & $3.33 \%$ \\
Louse & $6.66 \%$ & $10.00 \%$ & $13.33 \%$ \\
Fleas & $10.00 \%$ & $13.33 \%$ & $10.00 \%$ \\
\hline
\end{tabular}

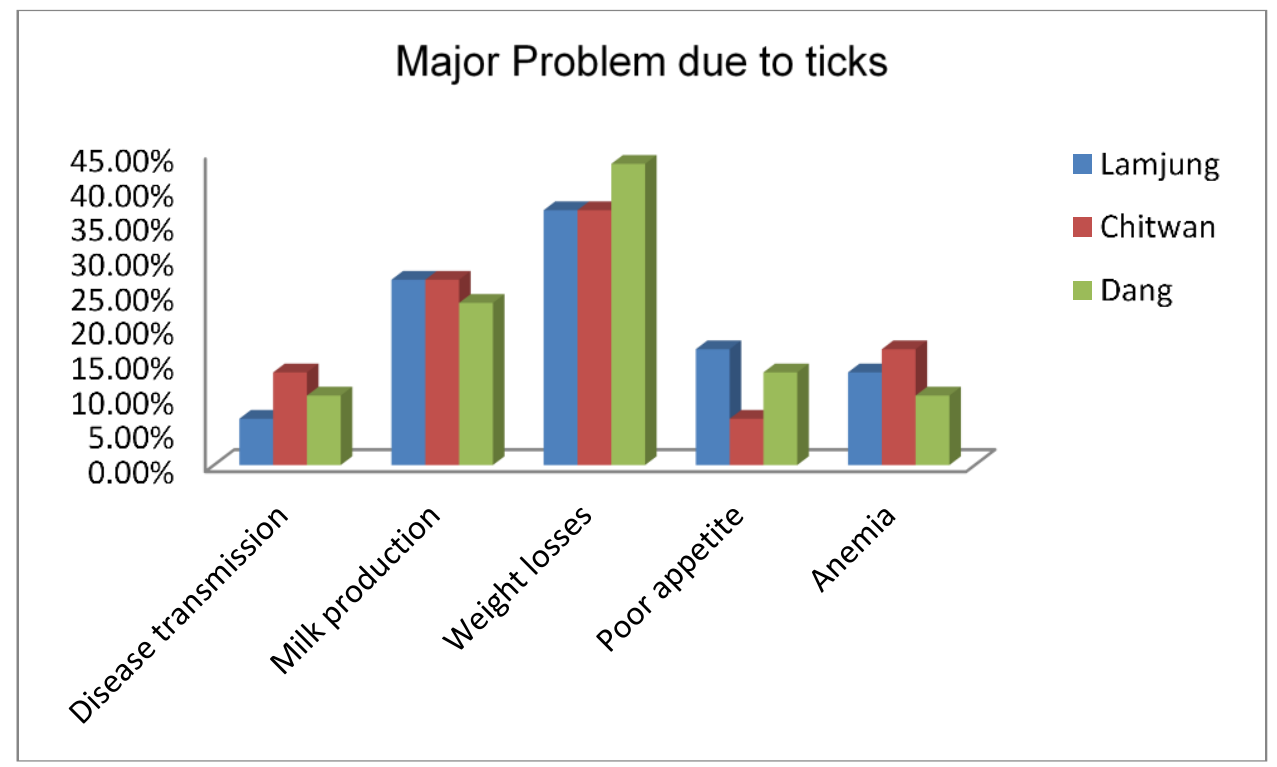

Figure 1. Major problem due to ticks in Lamjung, Chitwan and Dang, 2017/018.

problem in livestock due to ticks in all surveyed areas. Less than half respondent in Dang (43.33\%) followed by Lamjung and Chitwan (36.66\%) responded that weight loss is the main problem caused by ticks. Similarly, nearly one-fifth of the farmers perceived reduction in milk production as the important problem due to ticks in Lamjung (26.66\%), Chitwan (26.66), and Dang (23.33\%). Few farmers also perceived disease transmission, poor appetite and anemia as the problem caused due to ticks (Figure 1).

\section{Frequently used plants species for ticks control}

Table 5 shows that Neem (Azadirachta indica) is the most commonly used plant species for the tick control followed by tobacco (Nicotiana tabacum). In Lamjung (46.66\%), Chitwan (46.66\%) and Dang (40.00\%) of the surveyed population used Neem (Azadirachta indica) as the remedial measure for tick control whereas tobacco (Nicotiana tabacum) was found to be effective by following percentage of the people viz Chitwan (40.00\%), Dang $(36.66 \%)$ and Lamjung $(30.00 \%)$ for the said purpose. Less than one-fifth farmers found using Bakaino (Melia azedarach) in Dang (16.66\%) followed by Lamjung (13.33\%) and Chitwan (10.00\%) as an effective plant for tick control. In Lamjung, $10 \%$ of the population as compared to Chitwan (3.33\%) and Dang (6.66\%) used Titepati (Artemisia vulgaris) as an alternate plant species for tick control. 
Table 5. Frequently used plants species for ticks control by farmer in Lamjung, Chitwan and Dang.

\begin{tabular}{lccc}
\hline Frequently used plants species for ticks control & Lamjung & Chitwan & Dang \\
\hline Titepati (Artemisia vulgaris) & $10.00 \%$ & $3.33 \%$ & $6.66 \%$ \\
Neem (Azadirachta indica) & $46.66 \%$ & $46.66 \%$ & $40.00 \%$ \\
Tobacco (Nicotiana tabacum) & $30.00 \%$ & $40.00 \%$ & $36.66 \%$ \\
Bakaino (Melia azedarach) & $13.33 \%$ & $10.00 \%$ & $16.66 \%$ \\
\hline
\end{tabular}

Table 6. Other local material for ticks control by farmer in Lamjung, Chitwan and Dang.

\begin{tabular}{lccc}
\hline Other local material for ticks control & Lamjung & Chitwan & Dang \\
\hline Salt water & $96.66 \%$ & $93.33 \%$ & $93.33 \%$ \\
Soap Water & $3.33 \%$ & $6.66 \%$ & $6.66 \%$ \\
\hline
\end{tabular}

Table 7. Farmers experienced on efficacy of different product against ticks in Lamjung, Chitwan and Dang.

\begin{tabular}{lccc}
\hline Efficacy of control & Lamjung & Chitwan & Dang \\
\hline Titepati (Artemisia vulgaris) & $6.66 \%$ & $3.33 \%$ & $3.33 \%$ \\
Neem (Azadirachta indica) & $20.00 \%$ & $23.33 \%$ & $23.33 \%$ \\
Tobacco (Nicotiana tabacum) & $6.66 \%$ & $10.00 \%$ & $10.00 \%$ \\
Bakaino (Melia azedarach) & $3.33 \%$ & $6.66 \%$ & $3.33 \%$ \\
Salt water & $63.33 \%$ & $56.66 \%$ & $60.00 \%$ \\
\hline
\end{tabular}

Table 8. Management practices adapted by farmers for the ticks by farmer in Lamjung, Chitwan and Dang.

\begin{tabular}{lccc}
\hline Management practices for ticks & Lamjung & Chitwan & Dang \\
\hline Chemical Method & $30.00 \%$ & $40.00 \%$ & $30.00 \%$ \\
Ethno-veterinary Method & $26.66 \%$ & $20.00 \%$ & $30.00 \%$ \\
Hand Picking and grooming & $40.00 \%$ & $36.66 \%$ & $33.33 \%$ \\
No management practices & $3.33 \%$ & $3.33 \%$ & $6.66 \%$ \\
\hline
\end{tabular}

\section{Other local material used for ticks control}

Farmers were asked about other local materials used in tick control except plant products and result is presented in Table 6. Nearly all the farmers found salt water as the most effective local material for the tick control. Highest numbers of farmer were found using salt water in Lamjung $(96.66 \%)$ followed by equal numbers in Chitwan and Dang $(93.33 \%)$.

\section{Efficacy of different product against ticks}

Table 7 presented the efficacy of different product against ticks in different surveyed areas. As per the data collected, salt water was found most effective against ticks in all surveyed areas viz Lamjung (63.33\%), Chitwan (56.66\%) and Dang $(60.00 \%)$. Similarly, about one-fourth farmers responded that Neem (Azadirachta indica) is an effective tick control, in Lamjung (20.00\%), Chitwan and Dang (23.33\%). Titepati (Artemisia vulgaris), Tobacco (Nicotiana tabacum), Bakaino (Melia azedarach) were also reported by few farmers as the effective ethnoveterinary practice for the control of ticks in livestock.

\section{Management practices for ticks}

Table 8 shows the control measure followed by the farmers in surveyed areas. Hand picking and grooming were found as the main control method for the ticks in Lamjung $(40.00 \%)$ and Dang $(33.33 \%)$ whereas chemical control was found effective in Chitwan by $40.00 \%$ farmers. Highest numbers of farmers in Dang $(30.00 \%)$ were found using ethno-veterinary method for the control of ticks followed by Lamjung (26.66\%) and Chitwan (20.00\%). Very few farmers in all surveyed areas did nothing for tick control. This was highest in Dang (6.66\%) followed by 
equal values in Lamjung and Chitwan (3.33\%).

\section{DISCUSSION}

Both agriculture and animal husbandry have gone hand in hand for generations in Nepal. Majority of the people reared animals for household consumption and the excess produce were sold in market. Large number of people raised small number of livestock which is based on subsistence necessity of farmer rather than marketing purpose (Pradhanang et. al., 2015). Present findings of this research were in line with the several previous reports. According to Laisser et al. (2015), farmers in Tanzania also reported diseases and pests as the main problem of livestock farming. Regarding the control of ticks, Kerario et al. (2018) reported that majority of the farmers $(87.5 \%)$ using acaricides and small proportion of them (12.5\%) doing nothing to control ticks on their cattle. Wanzala et al. (2012) reported that farmers in western Kenya practices handpicking and ethnobotanical suspensions as traditional methods of ticks control. The farmers $(59 \%)$ were using acaricide to control ticks in Tanzania (Chenyambuga et al., 2010). Tick-borne diseases cause high morbidity and mortality and lead to reduced growth rate, milk production, and fertility (Laisser et al., 2017). In the present study, farmers also reported weight losses, reduce in milk yield, disease transmission as the major problems due to ticks. Ghosh et al. (2007) reported that Neem (Azadirachta indica) effectively work against ticks. Tobacco (Nicotiana tabacum) is used in eradication of external pest of cattle infestation and mange (Davidovic et al., 2011). Zewdie (2010) reported salt water as the effective control measure for the control of ticks. According to the Tvedten (2016) salt desiccated and killed the ticks. Farmers in Punjab, India resort to the external application of grated/powdered common salt for tick control (Muhammad et al., 2008). This study also reported that majority of farmers used salt water to control ticks. In all surveyed areas, farmers were found to hand pick the ticks without wearing gloves or using forceps. They were advised about the zoonotic risks and were suggested to remove the ticks using gloves or forceps.

\section{Conclusion}

It is concluded that ticks causes serious problem in livestock from mid hills to plains of Nepal. Farmers were managing ticks based on different ethno-veterinary knowledges and practices. It is recommended that further studies should be done on ethno-veterinary knowledge and practices of ticks control in these areas.

\section{REFERENCES}

ADS (2012). Agricultural Development Strategy Assessment; Government of Nepal, ADB, IFAD, EU, FAO, SDC, JICA, WFP, USAID, DANIDA, DfID and World Bank: Kathmandu, Nepal.
Alemu, G., Chanie, M., Mengesha, D., \& Bogale, B. (2014). Prevalence of ixodid ticks on cattle in Northwest Ethipia. Acta Parasitologica Globalis, 5(2), 139-145.

Bohara, T. P., \& Shrestha, S. P. (2016). A study on cattle tick and tick borne pathogens of Mid-Western. Nepalese Veterinary Journal, 33, 23-27.

Bowman, A. S., Dillwith, J. W., \& Sauer, J. R. (1996). Tick salivary prostaglandins: presence, origin and significance. Parasitology Today, 12, 388-396.

Castro-Janer, E., Martins, J. R., Mendes, M. C., Namindome, A., Klafke, G. M., Schumaker, T. T. S. (2010). Diagnoses of fipronil resistance in Brazilian cattle ticks (Rhipicephalus (Boophilus) microplus) using in vitro larval bioassays. Veterinary Parasitology, 173, 300-306.

Chenyambuga, S. W., Waiswa, C., Saimo, M., Ngumi, P., \& Gwakisa, P. S. (2010). Knowledge and perceptions of traditional livestock keepers on tick-borne diseases and seroprevalence of Theileria parva around Lake Victoria Basin. Livestock Research for Rural Development, 22(7) Available at http://www.Irrd.org//rrd22/7/chen22135.htm.

Davidovic, V., Todorovic, M. J., Maksimovic, Z., Hristov, S., Stankovic, B., \& Relic, R. (2011). A review of plants used in Ethnoveterinary medicine. Macedonian Journal of Animal Science, 1(2), 377-382.

Domingues, L. N., Brasil, B. S. A. F., Bello, A. C. P. P., da Cunha, A. P., de Barros, A. Y. M., Leite, R. C., Silaghi, C., Pfister, K. \& Passos, L. M. F. (2012) Survey of pyrethroid and organophosphate resistance in Brazilian field populations of Rhipicephalus (Boophilus) Microplus: Detection of C190A mutation in domain II of the para-type sodium channel gene. Veterinary Parasitology, 189, 327-332.

Ducornez, S., Barre, N., Miller, R. J., \& deGarine-Wichatisky, M. (2005). Diagnosisofamitraz resistance in Boophilus microplus in New Caledoniawith modified larval packet test. Veterinary Parasitology, 130, 285-292.

Ghosh, S., Azhahianambi, P., \& Yadav, M. P. (2007). Upcoming and future strategies of tick control: a review. Journal of Vector Borne Disease, 44, 79-89.

Gupta, V., Gupta, R., \& Shrestha, S. P. (2013). Infectivity of Theileria annulata in Hyalomma ticks of Eastern Terai districts. Nepal Nepalese Journal of Zoology, 1(1), 15-23.

Itty, P., Swallow, B. M., Rowlands, G. J., Mulatu, W., \& d'leteren G. D. M. (1995). The economics of village cattle production in a tsetse-infested area of southwest Ethiopia. Preventive Veterinary Medicine, 22 (3), 183-196.

Kerario, I. I., Simuunza, M., Laisser, E. L. K., \& Chenyambuga, S. (2018). Exploring knowledge and management practices on ticks and tick-borne diseases among agro-pastoral communities in Southern Highlands, Tanzania. Veterinary World, 11(1), 48-57.

Kumar, S., Paul, S., Sharma, A. K., Kumar, R., Tewari, S. S., Chaudhuri, P., Ray, D. D., Rawat, A. K. S., \& Ghosh, S. (2011). Diazinon resistant status in Rhipicephalus (Boophilus) microplus collected from different agro-climatic regions of India. Veterinary Parasitology, 181, 274-281.

Laisser, E. L. K., Chenyambuga, S. W., Karimuribo, E. D., Msalya, G., Kipanyula, M. J., Mwilawa, A. J., Mdegela, R. H., \& Kusiluka. L. J. M. (2017). A review on prevalence, control measure, and tolerance of Tanzania Shorthorn Zebu cattle to East Coast fever in Tanzania. Tropical Animal Health Production, 49, 813-822.

Laisser, E. L. K., Chenyambuga, S. W., Msalya, G, Kipanyula, M. J., Mdegela, R. H., Karimuribo, E. D., Mwilawa, A. J., \& Kusiluka, L. J. M. (2015). Knowledge and perception on ticks, 
tick-borne diseases and indigenous cattle tolerance to East Coast fever in agro-pastoral communities of Lake Zone in Tanzania. Livestock Research for Rural Development, 27(4). Available at http://lrrd.cipav.org.co//rrd27/4/lais27064.htm

Mendes, M. C., Lima, C. K. P, Nogueira, A. H. C., Yoshihara, E., Chiebao, D. P., Gabriel, F. H. L, Ueno, T. E .H., Namindome, A., \& Klafke, G. M. (2011). Resistance to cypermethrin, deltamethrin and chlorpyriphos in populations of Rhipicephalus (Boophilus) microplus (Acari: Ixodidae) from small farms of the State of São Paulo, Brazil. Veterinary Parasitology, 178, 383388.

MoAD. (2014). Ministry of Agricultural Development: Statistical information on Nepalese agriculture. Kathmandu: Ministry of Agricultural Development. Singhdurbar, Kathmandu.

Mondal, D. B., Sarma, K. \& Saravanan, M. (2013). Upcoming of the integrated tick control program of ruminants with special emphasis on livestock farming system in India. Ticks Tick Borne Disease, 4, 1-10.

Muhammad, G., Naureen, A., Firyal, S., \& Saqib, M. (2008). Tick control strategies in dairy production medicine. Pakistan Veterinary Journal, 28(1), 43-50.

Pradhanang, U. B, S. M. Pradhanang, A. Sthapit, N. Y. Krakauer, A. Jha \& T. Lakhankar. (2015). National Livestock Policy of Nepal: Needs and Opportunities. Agriculture, 5, 103-131.

Rajput, Z. I., Hu, S., Chen, W., Arijo, A. G., \& Xiao, C. (2006). Importance of ticks and their chemical and immunological control in livestock. Journal of Zhejiang University Science, 7(11), 912-921.

Sarani, M., Telmadarraiy, Z., Moghaddam, A. S., Azam, K. \& Sedaghat, M. M. (2014). Distribution of ticks (Acari: Ixodidae) infesting domestic ruminants in mountainous areas of Golestan province, Iran. Asian Pacific Journal of Tropical Biomedicine, 4, 246-251.
Shrestha, S. P., Deo, S. N., Acharya, M. P., \& Kunwar, B. L. (2005). Mapping of livestock tick fauna of different agroclimatic zonesof Nepal. Nepalese Veterinary Journal 28, 7377.

Tvedten, S. (2016). The best control for ticks, mites, mold and fungi. Chapter 20, 34. Available at https://www.yumpu.com/en/document/view/49510864/chapter -20-the-best-control-for-ticks-mites-mold-and-fungi.

Upadhyay, N. D., Timsina, K. P., Gairhe, S., Sapkota, S., Acharya, Y., \& Khadka, S. (2017). Growth of livestock sector in Nepal: a perspective on agriculture perspective plan. Proceeding of the 10 National Workshop on Livestock and Fisheries Research in Nepal, 5-7 March, 2017.

Wanzala, W., Takken, W., Mukabana, W. R., Pala, A. O., \& Hassanali, A. (2012). Ethnoknowledge of Bukusu community on livestock tick prevention and control in Bungoma district, western Kenya. Journal of Ethnopharmacology, 140, 298-324.

Zewdie, S. (2010). Control of external parasites of Sheep and Goats. Technical Bulletin No. 41. Published by Ethiopia Sheep and Goat Productivity Improvement Program 2010; 16. Available

http://www.esgpip.org/pdf/Technical\%20Bulletin\%20No.41.pd f. 